\title{
Belajar Otodidak untuk Mencapai Kompetensi Improvisasi bagi Pemain Keyboard Komunitas Band di Bandung
}

\section{Autodidact Learning to Achieve the Improvisation Competence for Keyboard Players Band Community in Bandung}

\author{
Nindya Maya Kartika \& Diah Latifah \\ Universitas Pendidikan Indonesia, Bandung, Jawa Barat, Indonesia \\ nindhymay@gmail.com
}

Naskah diterima tanggal 07/03/2019, direvisi akhir tanggal 22/04/2019, disetujui tanggal 30/04/2019

\begin{abstract}
Abstrak
Penelitian ini didasari atas kemampuan kreativitas improvisasi pemain keyboard pada band melalui belajar otodidak. Penelitian ini bertujuan untuk mengetahui proses belajar otodidak, meningkatkan kreativitas improvisasi pemain keyboard band dalam komunitas Band in Bandung. Metode penelitian menggunakan penelitian kualitatif single case design karena menekankan pada sebuah unit kasus dengan menggunakan teknik wawancara dan observasi untuk mendapatkan data hasil penelitian. Wawancara dilakukan dengan komunikasi mengenai proses awal bermain keyboard, cara untuk meningkatkan kreativitas improvisasi bermain keyboard. Observasi untuk mendapatkan data mengenai proses belajar otodidak guna meningkatkan kreativitas pemain keyboard. Hasil analisis data sebagai berikut: 1. Kreativitas pengembangan akor dengan menambahkan akor tambahan sebagai pemanis lagu, pengembangan melodi dengan menirukan nada-nada melodi tersebut, pengembangan kecepatan jari dengan latihan rutin melalui tangga nada dan nada-nada kromatik, 2 . Proses awal mengenal lagu dan improvisasi memainkan keyboard dengan mendengarkan lagu dan memberi variasi nada secara spontan serta menambahkan sound effect keyboard 3. Kekurangan terletak pada fingering yang tidak seharusnya dan keunggulan belajar keyboard secara otodidak adalah mempunyai rasa musikalitas yang tinggi. Kesimpulannya adalah belajar otodidak bisa untuk meningkatkan kreativitas improvisasi bermain keyboard.
\end{abstract}

Kata kunci: Belajar otodidak, Kreativitas, Improvisasi, Pemain Keyboard komunitas Band in Bandung.

\begin{abstract}
This research was based on the creativity ability to improvise the keyboard players in the band through autodidact learning. This study aims to determine the autodidact learning process, enhance the creativity of improvised Band in Bandung Community keyboard players. This research method uses a type of qualitative single case design because it emphasizes only on a unit of case by using interview techniques and observation to obtain research data. Interviews were conducted with communication about the initial process of playing the keyboard, ways to improve improvisational creativity playing the keyboard, then by observing researchers could get data about the autodidact learning process to improve creativity keyboard player until data on weaknesses and excess autodidact learning of creativity of players keyboard. The results of data analysis obtained the following results: 1. Creativity in developing chords by adding additional chords as song sweeteners, developing melodies by imitating these melodic tones, developing finger speed with regular practise through scales and chromatic tones 2. The initial process of knowing songs and improvisation plays the keyboard by listening to songs and giving variations of tone spontaneously and adding keyboard song effect 3. Weakness are located on fingering, not supposed to and the advantages of autodidact learning keyboard having a high musicality. The conclusion is autodidact learning can improve creativity improvisation playing the keyboard.
\end{abstract}

Keywords: Autodidact learning, Creativity, Improvisation, Band Community Keyboard Player in Bandung. 


\section{PENDAHULUAN}

Dewasa ini ditemui pemain keyboard dalam sebuah band yang belajar secara otodidak. Istilah otodidak dapat dimaknai sebagai self-directed learning. Menurut Gibbons (2002), self-directed learning adalah peningkatan pengetahuan, keahlian, prestasi, dan mengembangkan diri dimana individu menggunakan banyak metode dalam banyak situasi dalam setiap waktu.

Kemampuan yang dituntut pemain keyboard pada sebuah band adalah kemampuan improvisasi, kreativitas pengembangan akor, kreativitas mengembangkan melodi, kreativitas menentukan sound effect keyboard, dan kreativitas menentukan dan memainkan style keyboard. Untuk mengembangkan kemampuan improvisasi dan pengembangan akor diwakili oleh kreativitas pemain keyboard. Menurut Habsari (2005, hlm. 85) kreativitas musik adalah kemampuan seseorang untuk mencipta lagu, instrument ataupun mengaransemen musik baru yang belum pernah diciptakan orang lain dan hasil lagu dan musiknya dapat dinikmati orang lain. Kajian ini difokuskan pada kemampuan improvisasi pemain keyboard. Maftukhah (2010, hlm. 1) menjelaskan pengembangan kreativitas musik dapat dilakukan dengan cara mengembangkan improvisasi yang dilakukan oleh anak sesuai keinginan mereka. Mereka mengimprovisasi sendiri tanpa disadari atau spontan.

Improvisasi musik menurut Banoe (2003 , hlm. 193) adalah memainkan musik secara spontan tanpa perencanaan atau bacaan tertentu. Sedangkan improvisasi lagu menurut Hendro ( 2005, hlm. 2) suatu kebebasan dalam memainkan suatu notasi dengan tidak terikat atau tidak sama dengan notasi lagu aslinya. Kajian ini mengulas belajar kemampuan improvisasi secara otodidak bagi pemain keyboard band.

\subsection{Otodidak (Self-directed learning)}

Belajar secara otodidak berarti tanpa dorongan atau bimbingan dari luar, sehingga penguasaan dari hal-hal yang dipelajari harus dilakukan sendiri. Usaha penguasaan terhadap lagu baru dilakukan dengan mengerahkan daya upayanya untuk dapat menguasai lagu tersebut. Menurut Suparno (1997, hlm. 62) mengenai belajar otodidak adalah mereka sendiri yang membuat penalaran atas apa yang dipelajarinya dengan mencari makna, dan membandingkannya dengan apa yang telah dia ketahui serta menyelesaikannya ketegangan antara apa yang telah dia ketahui dengan apa yang dia perlukan dalam pengalaman yang baru.

Self-directed learning didefinisikan oleh Hiemstra (1994) sebagai kemampuan mengubah pembelajaran yang merupakan pengetahuan dan ilmu belajar dari satu situasi ke situasi lain. Sehingga self-directed learning bisa diartikan menjadi proses belajar yang berasal dari motivasinya sendiri, sehingga bisa belajar menemukan jalan keluar disetiap masalah dan bertujuan untuk mendapatkan ilmu dan pengalaman hidup yang baru. Tough (1971) menjelaskan bahwa:

Learners usually engage inlearning activities because of the benefits they expect to derive by doing so. Presumably, individuals engage in self-directed learning for similar purposes. In the case of peoplewho have acquired high-level professional skills on their own, this could mean that theyhave seen, beyond the anticipated results of their learning venture, some practicaladvantage in opting for a self-directed mode of learning.

Dalam kutipan diatas Tough menyampaikan bahwa peserta didik biasanya terlibat dalam kegiatan belajar karena manfaat yang mereka harapkan bisa didapatkan dengan melakukannya. Sehingga, individu terlibat dalam proses belajar otodidak untuk tujuan yang sesuai apa yang diharapkan. 


\subsection{Kreativitas dalam Musik}

Kreativitas merupakan kemampuan seseorang untuk menghasilkan pekerjaan yang baru dan tepat guna. Selain itu, kreativitas merupakan suatu hal yang penting baik ditinjau dari aspek individual maupun sosial, dan dapat dimunculkan dengan mempelajari karya cipta yang sudah ada sebelumnya, untuk diperbaharui sehingga menghasilkan karya cipta baru Sternberg \& Wagner (1999, hlm. 3).

Pendapat lain disampaikan oleh Munandar, (1999, hlm. 168) tentang kreativitas adalah kemampuan untuk melihat atau memikirkan hal-hal yang luar biasa, yang tidak lazim, memadukan informasi yang tampaknya tidak berhubungan dan mencetuskan solusi-solusi baru atau gagasangagasan baru, yang menunjukkan kelancaran, kelenturan, dan orisinalitas dalam berpikir.

Melalui musik seorang anak dapat mengembangkan imaji dan kreasi, mengkontribusikan ekspresi diri, serta kreativitas. Selain itu, musik juga dapat merangsang kreativitas dan individualitas. Hal inilah yang menjadi alasan mengapa musik disejajarkan dengan disiplin dasar lainnya (Djohan, 2005, hlm. 211).

\subsection{Improvisasi}

Improvisasi merupakan kegiatan spontan dan bebas dalam memainkan sebuah lagu tanpa terikat oleh notasi atau terikat oleh lagu aslinya sehingga berbeda dari lagu aslinya. Menurut Samboedi (1989) kehandalan (pengetahuan dan kemampuan) seseorang musisi merupakan penentu bagi bagusnya suatu improvisasi, namun kondisi perasaan musisi pun sangat berpengaruh besar dalam improvisasi. Berdasarkan pendapat diatas dapat disimpulkan bahwa improvisasi tidak dimainkan dengan asal atau tanpa pemikiran tetapi secara teknik juga harus benar-benar dikuasai. Selain membutuhkan pengetahuan dan kemampuan teknik yang memumpuni, improvisasi memerlukan rasa musikalitas yang baik karena berpengaruh untuk hasil baik dan tidaknya dalam suatu improvisasi.

Menurut Kennan (2004, hlm. 24) Improvisasi adalah merangkai nada secara langsung atau membuat variasi yang berdasarkan tema lagu, pada sebuah instrumen secara spontan. Kemudian menurut Hardjana (2004, hlm. 406) improvisasi adalah teknik tertua dalam permainan musik sepanjang zaman sebelum manusia mengenal peradaban tulis menulis, di bumi ini lebih banyak musik yang dimainkan secara improvisasi daripada dengan teks.

\section{METODE PENELITIAN}

Metode penelitian yang digunakan adalah Studi kasus dengan pendekatan Single case design. Studi kasus adalah sebuah studi kasus dapat didefinisikan sebagai studi intensif tentang seseorang, sekelompok orang atau unit yang ditujukan untuk menggeneralisasi beberapa unit. Penelitian kualitatif dengan studi kasus bertujuan untuk meneliti suatu permasalahan melalui studi kasus yang terdiri dari unit tunggal yaitu berarti satu orang, sekelompok penduduk, atau sekelompok masyarakat di suatu daerah dengan masalah tertentu (Creswell, 2015).

Dalam studi kasus fokusnya didasarkan pada unit khusus (Aidos dkk., 2002). Definisi lain yang serupa yaitu kasus studi adalah analisis sistem yang dipelajari dengan pandangan komprehensif oleh salah satu atau beberapa metode (Armstrong, 2011). Studi ini ditujukan kepada seseorang atau sekelompok orang yang belajar bermain keyboard secara mandiri.

Single case design adalah suatu penelitian studi kasus yang menekankan penelitian hanya pada sebuah unit kasus saja. Single case design digunakan bila peneliti menemukan kasus tertentu yang unik, kasus 
yang kritis.

Tellis (1997) "single case studies are also ideal for revelatory cases where an observer may have access to a phenomenon that was previously inaccessible." Studi kasus tunggal sangat ideal untuk kasus- kasus yang tersembunyi. Pada kasus tersebut pengamat dapat memasuki fenomena yang sebelumnya tidak dapat diakses. Adapun gambar 1 merupakan desain penelitian tunggal penelitian ini.

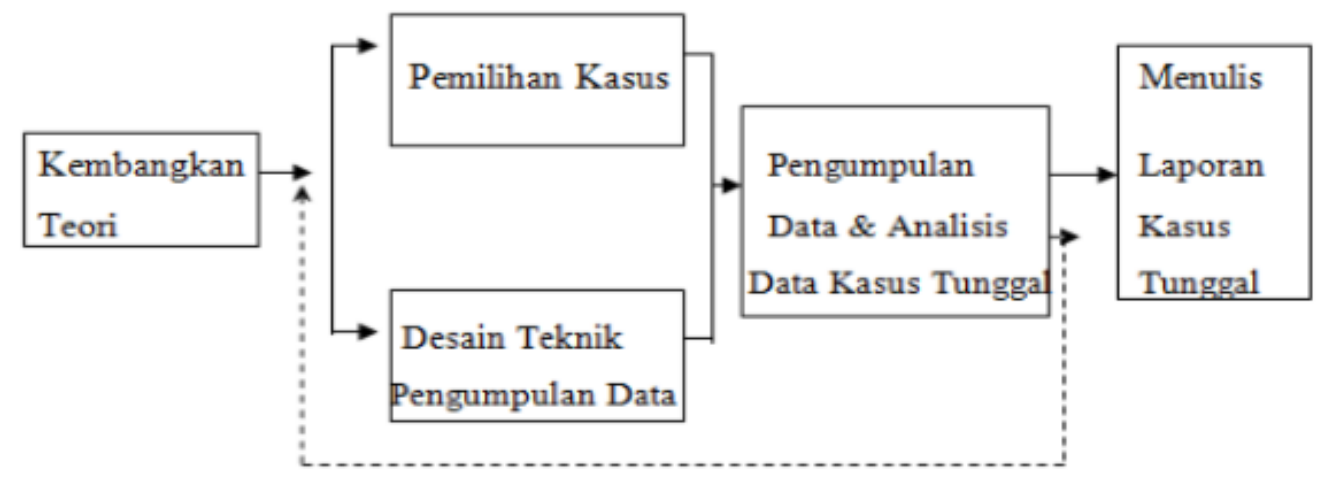

Gambar 1. Desain Penelitian Kasus Tunggal

Dalam penelitian ini, partisipan yang terlibat adalah pemain keyboard band pada komunitas Band in Bandung. Partisipan berjumlah 2 orang yang masing-masing keyboardist dalam band Vicanola dan HyOne yaitu Echa sebagai partisipan ke-1 dan Imul sebagai partisipan ke-2. Mereka band yang lahir di Bandung yang tergabung pada komunitas Band in Bandung.

Teknik pengumpulan data dalam penelitian ini dilakukan dengan cara:

1. Observasi

Observasi dipergunakan untuk mengumpulkan data yang berkaitan dengan proses belajar mandiri bermain keyboard.

2. Studi dokumentasi

Studi dokumentasi diambil dengan berbentuk foto, video,rekaman dan dokumen-dokumen. Studi dokumentasi ini bertujuan untuk menguatkan dan melengkapi data hasil penelitian.

3. Wawancara

Wawancara dilaksanakan dengan melakukan wawancara tidak terstruktur dan terstruktur. Wawancara adalah percakapan dengan maksud tertentu percakapan dilakukan oleh dua pihak yaitu pewawancara (interviewer) yang mengajukan pertanyaan dan terwawancara (interviewee) yang memberikan jawaban atas pertanyaan tersebut (Moleong 2005, hlm. 186).

\section{HASIL DAN PEMBAHASAN}

\subsection{Hasil}

\subsubsection{Kreativitas mengembangkan akor, melodi dan kecepatan jari}

Hasil penelitian atau observasi yang dilakukan pada Echa mengenai kreativitas pengembangan akor adalah dia bisa memainkan progresi akor walau tidak mengetahui bahwa yang sedang dia mainkan memiliki istilah progresi akor, kemudian untuk permainan melodi dia mampu memainkn melodi pada keyboard dengan baik dan mempunyai kemampuan kecepatan jari yang cukup baik. Untuk permainan variasi melodi dia biasa memainkan sisipan nada kromatik saat memainkan lagu.

Kemudian untuk Imul, juga mempunyai kemampuan pengembangan akor yang baik. Seperti halnya Echa, Imul bisa memainkan progresi akor akan tetapi tidak mengetahui istilah proses perubahan akor 
yang dilakukan tersebut. Pada permainan melodi dia menggunakan scale atau tangga nada sebagai nada sisipan atau variasi yang biasa dimainkan dengan kecepatan jari yang cukup baik.

\subsubsection{Posisi penjarian (Fingering) dalam bermain keyboard}

Dari hasil penenlitian, didapatkan data untuk Echa dari segi penjarian lebih sering menggunakan jari 1,2,3 untuk menekan nada dan untuk chord Echa menggunakan jari 1,2,5 untuk tangan kanan dan kiri Sehingga saat melakukan permainan melodi echa cenderung menggunakan jari 1,2,3 namun dengan perpindahan yang cepat.

Sedangkan Imul untuk tangga nada menggunakan jari 1,2,4 dan sangat jarang menggunakan jari 5 untuk melodi. Dan untuk menekan chord menggunakan jari 1,2,4 atau 1,2,4,5. Apabila dipadukan saat menekan chord Imul menggunakan jari 1,2,5 untuk tangan kiri dan jari 1,2,4 untuk tangan kanan. Saat memainkan melodi dalam sebuah lagu, Imul menggunakan jari 1,2,3,4 dengan kecepatan jari yang cukup baik. Jari kelingking atau jari 5 untuk tangan kanan hampir sama sekali tidak pernah digunakan.

\subsubsection{Cara mengenal lagu dan Improvisasi}

Untuk proses menirukan lagu, Echa lebih kepada memainkan apa yang dia dengar walau tidak sama Dan echa lebih memainkan program keyboard untuk mengembangkan kemampuan improvisasi. Untuk Imul, saat mengenal lagu dia mendengarkan lagu yang dia suka kemudian menirukan dengan chord yang berbeda, sehingga tidak sama persis dengan lagu aslinya.

Dari hasil penelitian yang didapat, untuk cara improvisasi 2 keyboardis ini mempunyai cara yang berbeda. Untuk Echa, cara improvisasi dengan menambahkan nada sehingga terbentuk chord yang berbeda dengan lagu asli, kemudian permainan sound effect yang ada pada keyboard atau meminkan melalui style yang tersedia pada keyboard. Kemudian untuk Imul, improvisasi melalui permainan melodi dan mengembangkan chord, kemudian imul menambahkan permainan sound effect yang dia inginkan dan yang dia anggap cocok untuk lagu tersebut.

\subsubsection{Cara Mengenal dan Menentukan sound effect dalam permainan band}

Cara menentukan sound effect untuk Echa dengan mendengarkan lagu yang akan dimainkan terlebih dahulu, kemudian apabila lagu tersebut slow atau bertempo pelan mencari sound dengan nuansa lembut seperti strings, choir, tetapi untuk lagu bertempo cepat lebih sering menggunakan synth, analog pad atau elektrik piano. Dia lebih manual dengan persepsi auditif yaitu imul. Perspektif berbasis psikomotorik kinestetik pada permainan akor, yang berdasar sensitifitas musik.

Kemudian untuk Imul menentukan sound effect dengan menyesuaikan lagu yang dipilih, dan memberi sound yang menurutnya cocok atau sesuai dengan lagu, misal lagu slow atau pelan menempatkan strings sebagai layer, atau terompet dan saxophone. Kemudian untuk synth dia gunakan sebagai pemanis untuk lagu-lagu tertentu misal untuk lagu bertempo cepat dan bernuansa keras.

\subsubsection{Kekurangan dan keunggulan belajar keyboard secara otodidak}

Untuk Echa dari segi penjarian lebih sering menggunakan jari 1,2,3 untuk menekan nada dan untuk chord Echa menggunakan jari 1,2,4. Sedangkan Imul untuk tangga nada menggunakan jari 1,2,3,4 namun terkadang 1,2,4,5 bila dibutuhkan jari 5 untuk memainkan akor dan sangat jarang menggunakan jari 5 untuk melodi. Dan untuk menekan chord menggunakan jari 1,2,4,5.

Keunggulan terdapat pada rasa musikal dalam memainkan keyboard lebih baik, karena dari awal sudah dilatih untuk mendengar dan belajar mencari tau chord 
atau nada yang terdapat pada lagu. Sehingga apabila diminta untuk memainkan sebuah lagu atau karya yang sebelumnya sudah pernah didengar mereka akan bisa meraba chord atau melodi tanpa harus membaca partitur.

\subsection{Pembahasan}

\subsubsection{Kreativitas Mengembangkan akor, melodi dan kecepatan jari}

Dari hasil observasi yang dilakukan oleh peneliti mengenai pengembangan akor, melodi dan kecepatan jari pada tabel 1 dan tabel 2 untuk kedua partisipan mempunyai cara yang hampir sama. Mereka mengmbangkan akor dengan menambahkan nada-nada diluar nada akor atau variasi progresi akor yang membentuk chord baru sehingga menghasilkan suara yang berbeda. Untuk mengembangkan melodi mereka berlatih dengan mempelajari melodi lagu kemudian membuat varisasi-variasi pada nada-nada tersebut. Untuk melatih kecepatan jari, mereka berlatih rutin melalui memainkan nada-nada seperti tangga nada dengan pola penjarian yang berbeda dari aturan yang seharusnya, melodi lagu atau belajar nadanada kromatik.

Beberapa dari mereka yang belajar otodidak kurang mengetahui mengenai istilah progresi akor, ada yang bisa memainkan namun tidak tahu bahwa yang sedang dimainkan adalah progresi akor, dan kadangkala hanya memainkan akor dasar saat bermain keyboard.

Tabel 1. Hasil Observasi Peneliti Terhadap Pengembangan akor dan melodi dan Kecepatan jari Kepada Partisipan - 1

\begin{tabular}{|c|c|c|c|}
\hline \multirow{2}{*}{ No } & \multirow{2}{*}{ Aspek yang Diamati } & Indikator & \multirow{2}{*}{ Keterangan } \\
\hline & & Ada $\quad$ Tidak & \\
\hline 1 & Mampu mengembangkan chord & $\sqrt{ }$ & $\begin{array}{l}\text { Dengan menambahkan nada lain sehingga } \\
\text { membentuk chord baru }\end{array}$ \\
\hline 2 & $\begin{array}{l}\text { Mempunyai kemampuan memainkan } \\
\text { progres akor }\end{array}$ & $\sqrt{ }$ & $\begin{array}{l}\text { Kemampuan progresi akor baik walaupun } \\
\text { istilah progresi akor tidak diketahui oleh } \\
\text { partisipan }\end{array}$ \\
\hline 3 & Melakukan eksplorasi nada & $\sqrt{ }$ & $\begin{array}{l}\text { Mampu memainkan melodi dengan baik dan } \\
\text { lancar }\end{array}$ \\
\hline 4 & $\begin{array}{l}\text { Mampu memainkan nada dengan } \\
\text { cepat }\end{array}$ & $\sqrt{ }$ & $\begin{array}{l}\text { Kecepatan dalam memainkan beberapa } \\
\text { melodi baik dan mampu menggunakan } \\
\text { kecepatan jari yang baik }\end{array}$ \\
\hline
\end{tabular}

Tabel 2. Hasil Observasi Peneliti Terhadap Pengembangan akor dan melodi dan Kecepatan jari Kepada Partisipan - 2

\begin{tabular}{|c|c|c|c|}
\hline \multirow{2}{*}{ No } & \multirow{2}{*}{ Aspek yang Diamati } & Indikator & \multirow{2}{*}{ Keterangan } \\
\hline & & Ada Tidak & \\
\hline 1 & Mampu mengembangkan chord & $\sqrt{ }$ & $\begin{array}{l}\text { Pengembangan progresi akor } \begin{array}{r}\text { dengan } \\
\text { menambahkan nada lain } \\
\text { membentuk chord } \text { baru }\end{array} \\
\end{array}$ \\
\hline 2 & $\begin{array}{l}\text { Mempunyai kemampuan memainkan } \\
\text { progres akor }\end{array}$ & $\sqrt{ }$ & $\begin{array}{l}\text { Kemampuan progresi akor baik walaupun } \\
\text { istilah progresi akor tidak diketahui oleh } \\
\text { partisipan }\end{array}$ \\
\hline 3 & Melakukan eksplorasi nada & $\sqrt{ }$ & $\begin{array}{l}\text { Mampu memainkan melodi dengan baik dan } \\
\text { lancar }\end{array}$ \\
\hline 4 & $\begin{array}{l}\text { Mampu memainkan nada dengan } \\
\text { cepat }\end{array}$ & $\sqrt{ }$ & $\begin{array}{l}\text { Kecepatan dalam memainkan beberapa } \\
\text { melodi baik dan mampu menggunakan } \\
\text { kecepatan jari yang baik }\end{array}$ \\
\hline
\end{tabular}




\subsubsection{Posisi penjarian (Fingering) dalam bermain keyboard}

Dari hasil observasi yang dilakukan terhadap 2 partisipan terkait posisi penjarian seperti pada tabel 3 dan tabel 4 dalam bermain keyboard adalah, mereka menggunakan jari yang tidak sesuai aturan bermain keyboard. Karena dari awal belajar mereka mengutamakan kenyamanan jari untuk bermain keyboard tanpa memperhatikan atau mengikuti aturan penjarian bermain keyboard yang seharusnya.

Tabel 3. Hasil Observasi Peneliti Terhadap Posisi penjarian (Fingering) dalam bermain keyboard Kepada Partisipan- 1

\begin{tabular}{|c|c|c|c|c|}
\hline \multirow{2}{*}{ No } & \multirow{2}{*}{ Aspek yang Diamati } & Ind & ator & \multirow{2}{*}{ Keterangan } \\
\hline & & Ada & Tidak & \\
\hline 1 & $\begin{array}{l}\text { Menggunakan penjarian sesuai aturan } \\
\text { bermain keyboard }\end{array}$ & & $\sqrt{ }$ & $\begin{array}{l}\text { Tidak menggunakan aturan penjarian } \\
\text { bermain keyboard yang seharusnya }\end{array}$ \\
\hline 2 & $\begin{array}{l}\text { Kesulitan saat memainkan tuts dalam } \\
\text { keyboard }\end{array}$ & & $\sqrt{ }$ & $\begin{array}{l}\text { Kemampuan progresi akor baik walaupun } \\
\text { istilah progresi akor tidak diketahui oleh } \\
\text { partisipan }\end{array}$ \\
\hline
\end{tabular}

Tabel 4. Hasil Observasi Peneliti Terhadap Posisi penjarian (Fingering) dalam bermain keyboard Kepada Partisipan - 2

\begin{tabular}{|c|c|c|c|c|}
\hline \multirow{2}{*}{ No } & \multirow{2}{*}{ Aspek yang Diamati } & \multicolumn{2}{|c|}{ Indikator } & \multirow{2}{*}{ Keterangan } \\
\hline & & Ada & Tidak & \\
\hline 1 & $\begin{array}{l}\text { Menggunakan penjarian sesuai aturan } \\
\text { bermain keyboard }\end{array}$ & & $\sqrt{ }$ & $\begin{array}{l}\text { Tidak menggunakan aturan penjarian } \\
\text { bermain keyboard yang seharusnya }\end{array}$ \\
\hline 2 & $\begin{array}{l}\text { Kesulitan saat memainkan tuts dalam } \\
\text { keyboard }\end{array}$ & & $\sqrt{ }$ & $\begin{array}{l}\text { Saat memainkan keyboard tidak kesulitan } \\
\text { walau penjarian dalam bermain keeyboard } \\
\text { tersebut adalah tidak benar. }\end{array}$ \\
\hline
\end{tabular}

\subsubsection{Cara Mengenal Lagu dan Improvisasi}

Dari hasil observasi yang didapatkan, kedua partisipan ini mempunyai cara improvisasi yang hampir sama. Mereka samasama mengandalkan nada tambahan pada akor atau variasi progresi akor untuk membuat sebuah lagu lebih terdengar berbeda dari lagu aslinya. Akan tetapi yang membedakan adalah hasil kreativitas yang mereka lakukan untuk sebuah musik. Karena menggunakan jenis keyboard yang berbeda, sehingga dapat ditemuka perbedaan yang lebih terlihat. Untuk Echa, karena menggunakan keyboard tunggal yaitu keyboard Yamaha PSRS-970 dengan fitur style dan song, dia berkreasi dengan fitur program yang ada pada keyboard tersebut. Jadi improvisasi yang dihasilkan adalah untuk iringan seperti elektone, dengan variasi sound effect yang dia pilih. Sedangkan untuk Imul, karena keyboard yang digunakan adalah keyboard synthesizer, jadi dia lebih berfokus mengembangkan improvisasi melalui sound effect yang ada pada keyboardnya. Kemudian dia memainkan dengan cara memainkan iringan keyboard dengan sound effect kreasinya.

\subsubsection{Cara Mengenal dan Menentukan sound effect dalam permainan band}

Dari hasil penelitian mengenai cara mengenal dan menentukan sound effect pada keyboard pada tabel 5 dan tabel 6 adalah mereka sama-sama mengenal sound effect saat memasuki dunia band. Saat mereka bergabung dalam sebuah band, mereka baru mempelajari mengenai sound effect dan fungsi setiap effect sound agar tepat untuk ditempatkan pada bagian lagu.

Untuk Echa, karena dari awal belajar keyboard untuk dimainkan sendiri, sehingga permainannya pun lebih kepada piano, dan 
saat bergabung dengan band, dia mulai belajar untuk memainkan sound effect untuk disesuaikan kepada materi lagu pada bandnya.. Kemudian untuk Imul, karena dia dari awal belajar keyboard untuk band, sehingga dari awal dia sudah mulai belajar sound effect keyboard saat awal mula belajar keyboard. Jadi permainan keyboard dia memang untuk bergabung dalam suatu band.

Dalam proses mengenal dan menentukan sound effect tidak lepas dari kreativitas oleh masing-masing individu. Sound effect yang diberikan juga tidak akan sama. Menurut (Munandar, 2004, hlm. 25) kreativitas adalah kemampuan memulai ide, melihat hubungan yang baru, atau tak diduga sebelumnya, kemampuan memformulasikan konsep yang tak sekedar menghafal, menciptakan jawaban baru untuk soal-soal yang ada, dan mendapatkan pertanyaan baru yang perlu dijawab. Dan menurut Djohan, (2005, hlm. 211), Melalui musik seorang anak dapat mengembangkan imaji dan kreasi, mengkontribusikan ekspresi diri, serta kreativitas. Selain itu, musik juga dapat merangsang kreativitas dan individualitas. Hal inilah yang menjadi alasan mengapa musik disejajarkan dengan disiplin dasar lainnya dan penting untuk dihadirkan di dalam pendidikan.

Tabel 5. Hasil Observasi Peneliti Terhadap Cara Mengenal Lagu dan Improvisasi kepada Partisipan - 1

\begin{tabular}{|c|c|c|c|}
\hline \multirow{2}{*}{ No } & \multirow{2}{*}{ Aspek yang Diamati } & Indikator & \multirow{2}{*}{ Keterangan } \\
\hline & & Ada Tidak & \\
\hline 1 & $\begin{array}{l}\text { Mampu melakukan improvisasi lagu } \\
\text { dengan baik }\end{array}$ & $\sqrt{ }$ & $\begin{array}{l}\text { Kemampuan improvisasi baik, kreativitas } \\
\text { dalam mengembangkan lagu baik. } \\
\text { Mempunyai rasa musikalitas yang baik }\end{array}$ \\
\hline 2 & Mampu memainkan lagu asli & $\sqrt{ }$ & Bisa memainkan lagu aslinya \\
\hline 3 & Membuat varian melodi & $\sqrt{ }$ & Membuat melodi sesuai kreasinya sendiri \\
\hline 4 & Membuat variasi chord & $\sqrt{ }$ & $\begin{array}{l}\text { Menambahkan nada lain untuk membuat } \\
\text { chord baru yang sesuai dan bisa dinikmati }\end{array}$ \\
\hline
\end{tabular}

Tabel 6. Hasil Observasi Peneliti Terhadap Cara Mengenal Lagu dan Improvisasi Kepada Partisipan - 2

\begin{tabular}{|c|c|c|c|}
\hline \multirow{2}{*}{ No } & \multirow{2}{*}{ Aspek yang Diamati } & Indikator & \multirow{2}{*}{ Keterangan } \\
\hline & & Ada Tidak & \\
\hline 1 & $\begin{array}{l}\text { Mampu melakukan improvisasi lagu } \\
\text { dengan baik }\end{array}$ & $\sqrt{ }$ & $\begin{array}{l}\text { Kemampuan improvisasi baik, kreativitas } \\
\text { dalam mengembangkan lagu baik. } \\
\text { Mempunyai rasa musikalitas yang baik }\end{array}$ \\
\hline 2 & Mampu memainkan lagu asli & $\sqrt{ }$ & Bisa memainkan lagu aslinya \\
\hline 3 & Membuat varian melodi & $\sqrt{ }$ & Membuat melodi sesuai kreasinya sendiri \\
\hline 4 & Membuat variasi chord & $\sqrt{ }$ & $\begin{array}{l}\text { Menambahkan nada lain untuk membuat } \\
\text { chord baru yang sesuai dan bisa dinikmati }\end{array}$ \\
\hline
\end{tabular}

\subsubsection{Kekurangan dan keunggulan belajar otodidak pemain keyboard di komunitas Band In Bandung}

Dari hasil penelitian, kekurangan bermain keyboard secara otodidak adalah saat prakteknya terdapat kekurangan seperti teknik penjarian. Keunggulan terdapat pada rasa musikalitas dalam memainkan keyboard lebih baik karena dari awal sudah dilatih untuk mendengar dan belajar mencari tau chord atau nada yang terdapat pada lagu, memainkan sound effect pada keyboard juga sangat baik. Karena mempelajari apa yang menadi kesukaan diri akan lebih mudah dan lebih menyenangkan.

Pengetahuan istilah musik seperti progresi akor, modulasi, tonalitas dan lainlain mungkin tidak semua pemain keyboard 
yang belajar secara otodidak mengetahuinya, sekalipun apa yang mereka lakukan adalah wujud dari istilah tersebut. Oleh dari itu, pentingnya sumber belajar yang lengkap dan akurat sangat berpengaruh terhadap hasil belajar.

Kekurangan dan keunggulan pasti dimiliki setiap proses belajar seperti pada tabel 7 dan tabel 8 untuk proses belajar bermain keyboard secara otodidak, banyak keunggulan dan kekurangan yang bisa digunakan sebagai pertimbangan saat akan memilih atau menggunakan metode belajar. Sedangkan kekurangan belajar otodidak adalah kita tidak mengetahui persis kebenaran ilmu yang kita dapat, informasi yang didapat hanya seperlunya atau tidak lengkap sehingga bisa membuat kesalahan saat menafsirkannya.

Tabel 7. Hasil Observasi Peneliti Terhadap Kekurangan dan Keunggulan Belajar Keyboard Secara Otodidak Kepada Partisipan - 1

\begin{tabular}{|c|c|c|c|c|}
\hline \multirow{2}{*}{ No } & \multirow{2}{*}{ Aspek yang Diamati } & \multicolumn{2}{|c|}{ Indikator } & \multirow{2}{*}{ Keterangan } \\
\hline & & Ada & Tidak & \\
\hline 1 & $\begin{array}{l}\text { Adanya kekurangan terhadap fingering } \\
\text { atau penjarian saat bermain keyboard }\end{array}$ & $\sqrt{ }$ & & $\begin{array}{l}\text { Teknik fingering atau penjarian tidak sesuai } \\
\text { dengan ketetapan fingering keyboard yang } \\
\text { seharusnya }\end{array}$ \\
\hline 2 & $\begin{array}{l}\text { Pemahaman mengenai teori dan istilah } \\
\text { dalam musik }\end{array}$ & & $\sqrt{ }$ & $\begin{array}{l}\text { Karena belajar secara otodidak sehingga } \\
\text { tidak begitu memperhatikan teori-teori yang } \\
\text { seharusnya dipelajari saat belajar bermain } \\
\text { keyboard, pengetahuan mengenai istilah } \\
\text { dalam musik juga kurang }\end{array}$ \\
\hline 3 & Kemampuan membaca partitur & & $\sqrt{ }$ & $\begin{array}{l}\text { Tidak bisa membaca partitur dan lebih } \\
\text { mengandalkan rasa musikalitasnya atau } \\
\text { feeling untuk bermain karya pada keyboard }\end{array}$ \\
\hline
\end{tabular}

Tabel 8. Hasil Observasi Peneliti Terhadap Kekurangan dan Keunggulan Belajar Keyboard Secara Otodidak Kepada Partisipan - 2

\begin{tabular}{|c|c|c|c|c|}
\hline \multirow{2}{*}{ No } & \multirow{2}{*}{ Aspek yang Diamati } & \multicolumn{2}{|c|}{ Indikator } & \multirow{2}{*}{ Keterangan } \\
\hline & & Ada & Tidak & \\
\hline 1 & $\begin{array}{l}\text { Adanya kekurangan terhadap fingering } \\
\text { atau penjarian saat bermain keyboard }\end{array}$ & $\sqrt{ }$ & & $\begin{array}{l}\text { Teknik fingering atau penjarian tidak sesuai } \\
\text { dengan ketetapan fingering keyboard yang } \\
\text { seharusnya }\end{array}$ \\
\hline 2 & $\begin{array}{l}\text { Pemahaman mengenai teori dan istilah } \\
\text { dalam musik }\end{array}$ & & $\sqrt{ }$ & $\begin{array}{l}\text { Karena belajar secara otodidak sehingga } \\
\text { tidak begitu memperhatikan teori-teori yang } \\
\text { seharusnya dipelajari saat belajar bermain } \\
\text { keyboard, pengetahuan mengenai istilah } \\
\text { dalam musik juga kurang }\end{array}$ \\
\hline 3 & Kemampuan membaca partitur & & $\sqrt{ }$ & $\begin{array}{l}\text { Tidak bisa membaca partitur dan lebih } \\
\text { mengandalkan rasa musikalitasnya atau } \\
\text { feeling untuk bermain karya pada keyboard }\end{array}$ \\
\hline
\end{tabular}

\section{KESIMPULAN}

Berdasarkan hasil pengolahan dan analisis data, peneliti menarik kesimpulan sebagai berikut; 1) Hasil penelitian terhadap 2 partisipan penelitia adalah mereka samasama mengembangkan akor, melodi dan kecepatan jari bermain keyboard melalui latihan rutin serta memainkan lagu untuk mencoba mencari nada yang bisa dikembangkan akor, melodinya kemudian untuk speed atau kecepatan jari lebih kepada improvisasi dan berlatih melodi secara rutin; 2) Hasil penelitian 2 partisipan dalam belajar bermain keyboard dan piano materi tentang 
penjarian atau fingering ternyata tidak sesuai aturan bermain keyboard yang seharusnya. Apabila mengikuti aturan posisi jari yang benar akan mempermudah untuk memainkan tuts keyboard. Akan tetapi dalam proses belajar otodidak, dalam bermain keyboard terkadang latihan penjarian sering kali diabaikan dan akhirnya membuat kebiasaan bermain keyboard dengan fingering yang tidak sesuai dengan aturan teknik penjarian yang seharusnya; 3) 2 partisipan ini mempunyai cara improvisasi atau berkreasi yang hampir sama yaitu mulai dengan mendengarkan lagu yang akan dimainkan, kemudianmemainkannya denganmenambahkan variasi nada yang berbeda tapi menurut mereka enak didengar dan bisa dinikmati oleh orang lain; 4) Dari hasil penelitian kepada 2 partisipan penelitian, untuk proses mengenal sound effect keyboard Echa dan Imul hampir sama yaitu dengan mendengarkan lagu tersebut dan mencari sound yang ada dalam lagu asli dan menirukan. Sehingga rasa musikal dari musisi ini sangat menentukan hasil dari penentuan sound effect yang akan digunakan dalam mengimprovisasi lagu; 5) Keunggulan pada echa terletak pada rasa musikal yang bagus sehingga bisa menjadikan alat musik keyboard sebagai partner bekerja. Kekurangan terletak pada penjarian yang tidak sesuai aturan yang seharusnya. Dia lebih sering menggunakan jari 1, 2, 3 untuk memainkan melodi dan tangga nada. Sedangkan utuk Imul, keunggulan pada rasa musikal dan kecepatan jari, tapi kekurangan pada fingering yang tidak sesuai. Hanya menggunakan jari 1, 2, 4 sebagai jari yang dominan digunakan dalam permainan keyboardnya.

\section{DAFTAR RUJUKAN}

Aidos I, C., Jacobsen, B., Jensen, J. B., Luten, A., Padt, R. M \& Boom. (2002). Volatile Oxidation. Bartlett Publisher Armstrong, T. (2011). The Best Schools: Mendidik Siswa Menjadi Insan Cerdekia Seutuhnya. Bandung: Kaifa Banoe, P. (2003). Kamus Musik. Yogyakarta: Kanisius

Creswell, J. W. (2015). Penelitian Kualitatif \& Desain Riset. Yogyakarta: Pustaka

Djohan. (2005). Pengaruh Stimulasi Elemen Tempo dan Timbre dalam Gamelan Jawa terhadap Respon Emosi Musikal. Yogyakarta

Gibbons, M. (2002). The Self Directed Learning Handbook Challenging Adolescent Student to Exel. San Fransisco: Jhon Wiley \& Sons, Inc.

Hardjana, S. (2004). Esai dan kritik musik. Yogjakarta: Galang Press

Hendro, S. D. (2005). Panduan praktis Improvisasi Piano Rock \& Blues. Jakarta: Puspa Swara

Suparno, P. (1997). Filsafat Konstruktivisme Dalam Pendidikan. Yogyakarta: Kanisius

Hiemstra, R. (1994). Self-directed learning. [Online]. Diakses dari http://home.twcny.rr.com/hiemstra/sdlhdbk. html.

Maftukhah, S. (2010). Kreativitas Musik dan Seni. [Online]. Artikel. Diakses dari http://edukasi.kompasiana. com/2010/11/04/kretivitas-musik-dan-seni315194.html

Moleong. (2005). Metodologi Kualitatif Edisi Revisi. Bandung: PT Remaja Rosdakarya

Munandar, Utami. (1999). Kreativitas dan Keberbakatan. Jakarta: Gramedia Pustaka

Munandar, Utami. (2004). Mengembangkan Bakat dan Kreatifitas Anak Sekolah. Jakarta: Gramedia Pustaka

Samboedi. (1989). Jazz Sejarah dan Tokoh-Tokohnya. Jakarta: Dahara Prizz

Sternberg, R. J., \& Wagner, R. K. (1999). Reading in cognitive psychology. USA: Thompson Learning

Tellis, W. (1997). Application of a Case Study Methodology, dalam The Qualitative terhadap Respon Emosi Musikal. Yogyakarta

Tough, A. (1971). The Adult's Learning Projects. Toronto: Ontario Institute for Studies In Education. 